Попов В. М., д.т.н. (Інститут водних проблем і меліорації НААН України, м. Київ), Таргоній М. М. (Інститут водних проблем і меліорації НААН України, м. Київ)

\title{
МАТЕМАТИЧНА МОДЕЛЬ АВТОМАТИЗОВАНОГО УПРАВЛІННЯМ ВОДОПОДАЧЕЮ НА ЗРОШУВАЛЬНІЙ СИСТЕМІ
}

Дослідження спрямовані на створення математичної моделі, що застосовується для обгрунтування алгоритмів автоматизованого управління водоподачею на закритій зрошувальній системі (33C) при застосуванні на насосній станції (HC) насосного агрегату (HA) 3 перетворювачем частоти (ПЧ).

Метою досліджень $є$ зменшення енергоємності машинної водоподачі на 33 шляхом ефективного застосування ПЧ на НС. Поставлено завдання: створення моделі автоматизованого управління водоподачею за блок-схемою 33С; проведення ідентифікації параметрів типових блоків моделі за результатами експериментальних досліджень; аналіз якості системи автоматичного регулювання (САР) напору води на виході НС.

Створено математичну модель 33С, як об'єкту розосередженого контролю та автоматизованого управління водоподачею, за її блоксхемою із застосуванням програми MATLAB/Simulink. Отримано динамічні та гідравлічні характеристики об'єктів за результатами експериментальних досліджень, проведених на 33С із застосуванням сучасних засобів вимірювальної техніки (ЗВТ). Здійснено ідентифікацію параметрів типових блоків математичної моделі - асинхронних електродвигунів, відцентрових насосів, засувок та інших блоків за перехідними характеристиками та функціональними залежностями, отриманими експериментально. Визначено гідравлічні характеристики закритої зрошувальної мережі (33М) із застосуванням розрахунково-експериментального методу. Розроблено математичну модель САР напору на виході НС для аналізу перехідних процесів автоматичного регулювання водоподачі та оптимізації параметрів пропорційно-інтегрального (ПІ) регулятора.

Ключові слова: математична модель, автоматизований електропривод, насосний агрегат, управління водоподачею, гідравлічні характеристики, перехідний процес. 
Актуальність досліджень. Комп'ютерне моделювання являється одним із основних методів аналізу систем автоматизованого управління технологічними процесами [1]. Вперше, в середовищі MATLAB/Simulink [2] розроблено математичну модель САУВ із застосуванням на підкачувальній НС частотно-керованого електропривода, як заходу з підвищення енергоефективності водоподачі на 33С.

Аналіз досліджень і публікацій. При обґрунтуванні ефективності застосування ПЧ на НС 33С враховують статистичні характеристики процесів водоподачі та електроспоживання [3; 4]. Математичне моделювання, що використовується для дослідження систем водоподачі та водовідведення [5; 6] не враховує технічні, гідравлічні характеристики та особливості режимів роботи 33С. Моделювання, представлене в роботі [7], відтворює процеси при дискретному управлінні водоподачею на 33С.

Вирішення завдання. Математична модель розробляється за блок-схемою САУВ, наведеною на рис. 1.

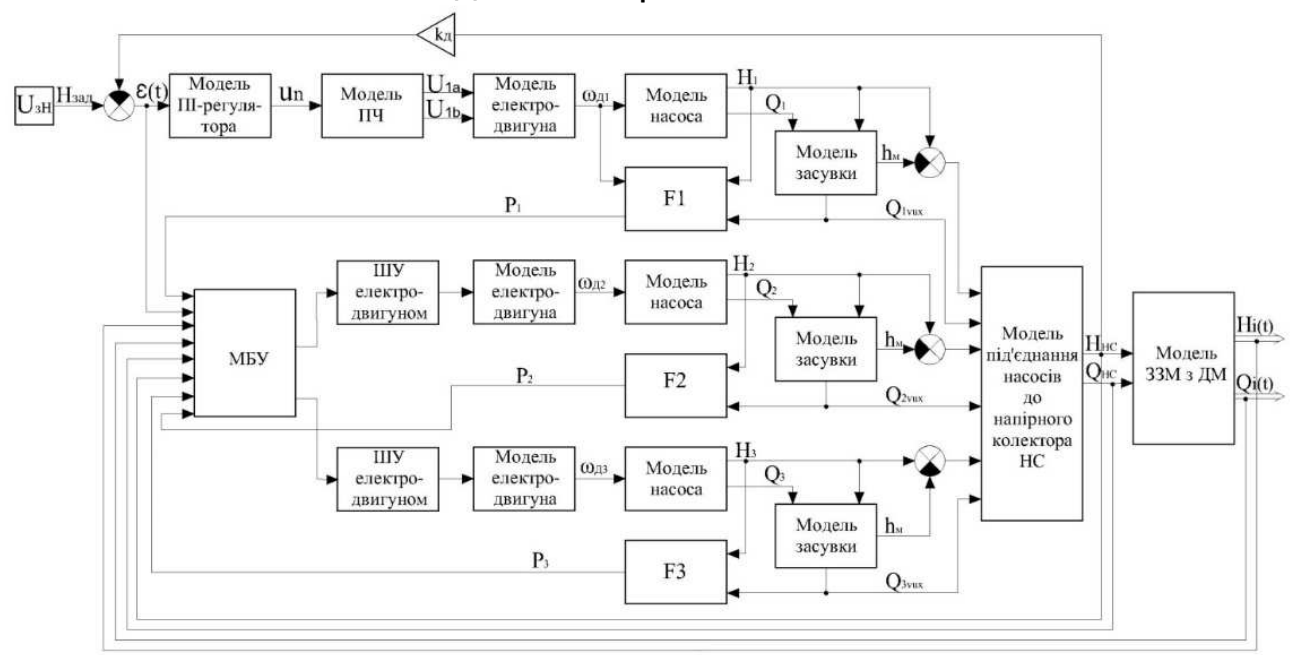

Рис. 1. Блок-схема САУВ із застосуванням автоматизованого електропривода на одному НА підкачувальної НС:

$\mathrm{U}_{3 н}$ - блок завдання; $\mathrm{H}_{\text {зад }}$ - заданий напір; $\varepsilon(\mathrm{t})$ - сигнал неузгодження; Un - сигнал керування; $U_{1 a}, U_{1 b}$ - векторна напруга статора; приводного електродвигуна, об/хв; $Q_{i}$ - об'ємна витрата води створювана i-тим HA, м³ $/$; $\mathrm{H}_{\mathrm{i}}$ - напір води $і$-того насосу, м; $\mathrm{P}_{\mathrm{i}}$ - фактична потужність споживана і-тим НА, кВт; $\mathrm{k}_{\text {д }}$ коефіцієнт передачі датчика тиску; F1,

F2, F3 - формули для визначення потужностей НA

Блок-схема моделі 33С складається з типових моделей: асинхронні електродвигуни, відцентрові насоси, запірно-регулювальна арматура та водоводи, моделі під'єднання насосів до колектора НС, 
модель 33М з дощувальними машинами (ДМ).

Параметри насосів визначаються за їхніми паспортними напірними характеристиками, а приводних електродвигунів - за робочими характеристиками. Електродвигун описується двома послідовно з'єднаними аперіодичними ланками першого порядку з електричною постійною часу $T_{e}$, механічною постійною часу $T_{\text {м }}$, та коефіцієнтом передачі $k_{\mathrm{A}}[1 ; 7]$.

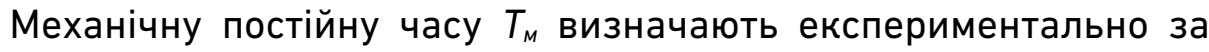
розгінною характеристикою приводного електродвигуна [8].

Тривалість аперіодичного перехідного процесу розгону електродвигуна $T_{p}$, як правило, в чотири рази перевищує постійну часу $T_{\text {м. }}$

Модель асинхронного електродвигуна представляють двома послідовно з'єднаними аперіодичними ланками, наведеними на рис. 2.

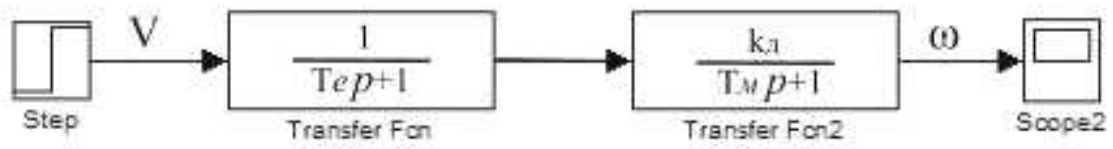

Рис. 2. Модель асинхронного електродвигуна

В моделі електродвигуна марки А4Н315-4У3 коефіцієнт передачі $\mathrm{k}_{\mathrm{B}}=0,0625$ об/B, а постійні часу: $\mathrm{T}_{e}=0,09 \mathrm{c} ; \mathrm{T}_{M}=0,30 \mathrm{c}$.

Модель асинхронного електродвигуна з частотно-керованим електроприводом представляють у вигляді структурної схеми [3].

Напірну характеристику відцентрового насоса в робочому діапазоні, представляють у вигляді відрізка параболи [4]:

$$
H=\mathrm{a}_{1} \mathrm{Q}^{2}+b_{1} \mathrm{Q}+c_{1} \text {, }
$$

де $\mathrm{H}$ - напір насоса, м; Q - об'ємна витрата води, створювана насосом, м³/год; $a_{1}, b_{1}, c_{1}$ - параметри формули, що розраховують за методом найменших квадратів.

Напірну характеристику насоса в середовищі MATLAB/Simulink описують стандартним блоком - Lookup Table, в якому параметри напору та витрати води подаються в табличному вигляді.

Зміни напору насоса та об'ємної витрати води в залежності від частоти обертання робочого колеса, визначають за співвідношенням:

$$
\frac{H_{\phi}}{H}=\left(\frac{\omega_{\phi}}{\omega}\right)^{2}, \frac{Q_{\phi}}{Q}=\frac{\omega_{\phi}}{\omega},
$$

де $H_{\phi}, Q_{\phi}, \omega_{\phi}$ - фактичні значення напору, об'ємної витати води та частоти обертання робочого колеса насоса. 
Модель засувки визначає місцеві втрати напору в залежності від ступеня їі відкриття. Динаміку відкриття засувки на виході насоса представляють передавальною функцією інтегратора [7]:

$$
W_{3}(p)=\frac{K_{3}}{p} \text {. }
$$

де $K_{3}$ - коефіцієнт передачі виконавчого механізму визначається за швидкістю відкриття засувки.

Витратна характеристика засувки задається однією із емпіричних формул, наведених в статі [7].

Місцеві гідравлічні втрати в засувках, поворотних затворах і зворотних клапанах розраховують за формулою [9]

$$
h_{M}=\xi \frac{V^{2}}{2 g}, \mathrm{M},
$$

де $\xi$ - коефіцієнт гідравлічного опору; $V$ - швидкість руху води, м/с.

Коефіцієнти гідравлічного опору засувок різних типів представлено в НД 33-6.2-01-2006 [9].

Модель гідравлічного процесу на виході із насоса 200D90-A при відкриванні засувки наведено на рис. 3.

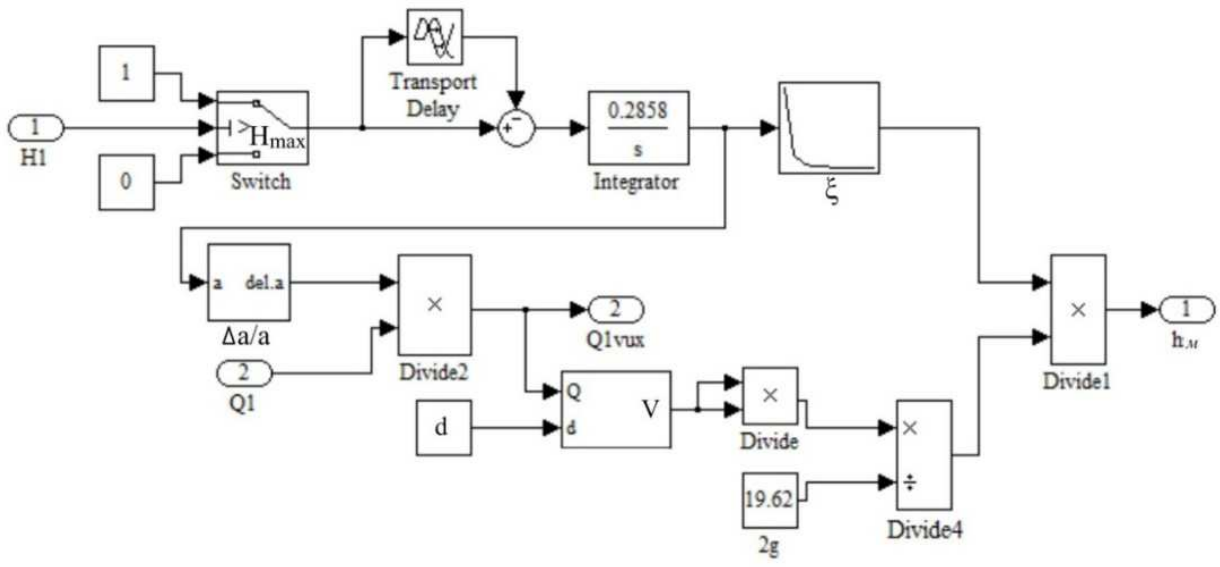

Рис. 3. Модель гідравлічного процесу на виході із насоса при відкриванні засувки:

Switch - логічний ключ (електроконтактний манометр на виході із насоса до засувки); Transport Delay - тривалість відкриття засувки

Модель «під'єднання насосів до напірного колектора НС» представляє собою багатоканальну гідравлічну систему подачі води НА до З3М з ДМ. Дана модель визначає місцеві втрати напору в зворотних клапанах, поворотах трубопроводів, гідравлічні втрати в місцях зміни діаметрів трубопроводів, місцеві втрати з врахуванням кутів 
під'єднання окремих водоводів до загального напірного трубопроводу (колектора) HC, а також гідравлічні втрати в напірних трубопроводах насосів станції.

Місцеві гідравлічні втрати визначаються за формулою (4), а значення коефіцієнтів гідравлічного опору наведені в роботах [7; 8].

Гідравлічні втрати в трубопроводах залежать від швидкості руху води, їх геометричних та гідравлічних характеристик і визначаються за формулою Дарсі-Вейсбаха [10]

$$
h_{\mathrm{V}}=\lambda \frac{l}{d} \cdot \frac{V^{2}}{2 g}, \mathrm{~m},
$$

де $\lambda$ - коефіцієнт шорсткості трубопроводу; $l$ - довжина трубопроводу, м; $d$ - внутрішній діаметр труби, м; $V$ - швидкість руху води, м/с; $g$ - прискорення вільного падіння, м/ $c^{2}$.

Модель гідравлічних втрат в трубопроводі, представлено на рис. 4.

Модель «під'єднання насосів до напірного колектора» розробляється з врахуванням гідравлічних втрат в трубопроводах, динамічних характеристик зміни напору та витрат води на виході HC.

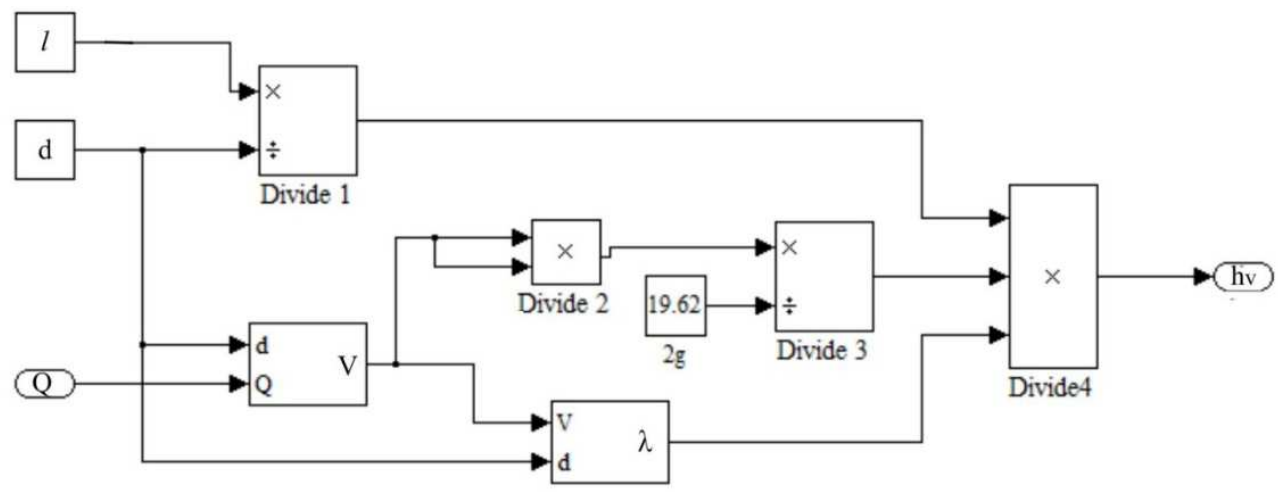

Рис. 4. Модель гідравлічних втрат в напірному трубопроводі

Структуру математичної моделі «під'єднання трьох насосів до напірного колектора $\mathrm{HC}$ »редставлено на рис. 5.

Перехідний процес зміни напору на виході із НС при зупинці ДМ представляють аперіодичною інерційною ланкою у вигляді передавальної функції:

$$
W(p)=\frac{k_{O}}{\left(T_{1} p+1\right)},
$$

де $k_{O}, \mathrm{c} / \mathrm{M}^{2}$ - коефіцієнт передачі ОУ водоподачею, який визначається експериментально за відношенням напору до витрати води на ви- 
ході із НС; $T_{1}$ - постійна часу, що визначається за тривалістю перехі-

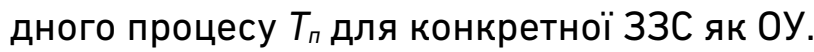

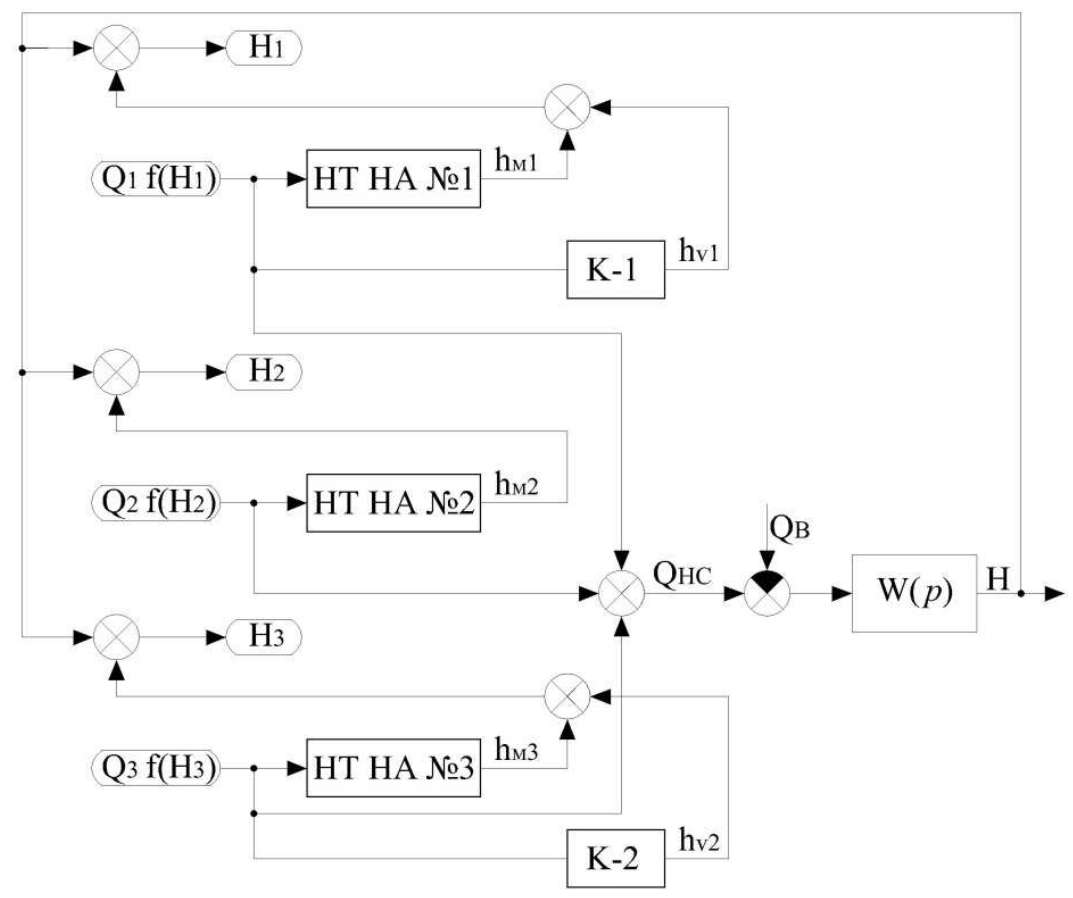

Рис. 5. Структура математичної моделі «під'єднання трьох насосів до напірного колектора $\mathrm{HC}$ :

HТ НА № 1, НТ НА № 2, НТ НА № 3 - блоки, що визначають місцеві гідравлічні втрати на запірно-регулювальній арматурі, на ділянках напірних трубопроводів насосів, переходах з одного діаметру трубопроводу на інший та на поворотах трубопроводів ; К-1 і К-2 - блоки місцевих гідравлічних втрат на ділянках напірного колектора. W(p) - передавальна функція, що характеризує динаміку напору на вході із НС при зміні об'ємної витрати води, створюваної НА під впливом збурюючи дій, що виникають на 33 С

При подачі води трьома HA типу 250QVD570-45 до десяти ДМ «Фрегат», $k_{O}=90 \mathrm{c} / \mathrm{M}^{2}, T \pi=500 \mathrm{c}, T_{1}=125 \mathrm{c}$.

Для розробки моделі З3М, як об'єкта розосередженого контролю, використовують конструктивні параметри трубопроводів та схеми розгалуженої мережі з ДМ за проектною та експлуатаційною документацією 33С. Для визначення параметрів моделі оцінюють гідравлічні характеристики 33М, визначають напірно-витратні характеристики ДМ та проводять ідентифікацію параметрів моделі із застосуванням розрахунково-експериментального методу [11]. При створенні моделі враховують також нетехнологічні втрати води на 33М, що змінюються в залежності від напору на виході НC. 
Фрагмент структурної схеми моделі реальної 33М 3 десятьма ДМ кругової дії типу «Otech», наведено на рис. 6.

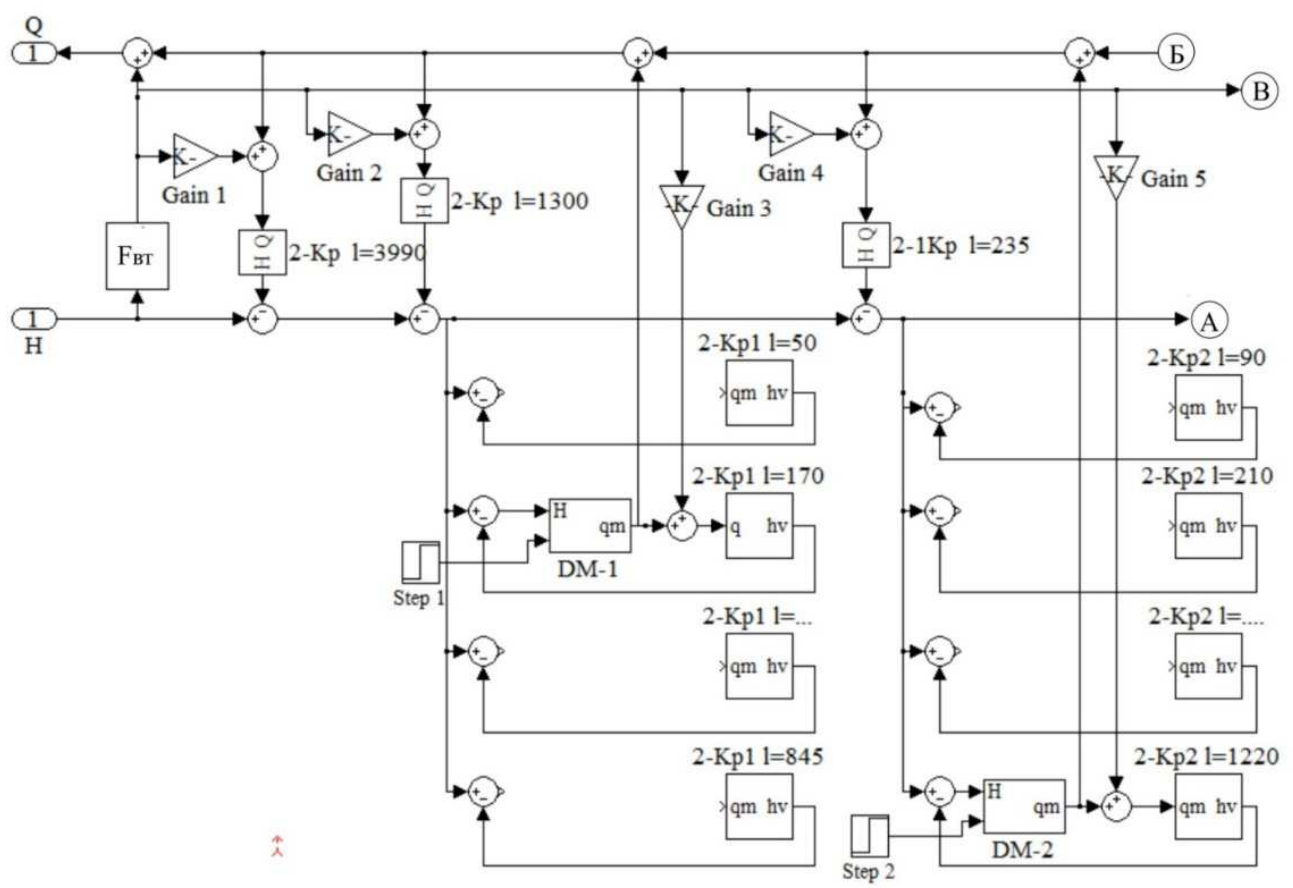

Рис. 6. Фрагмент структурної схеми моделі 33М:

H - напір на виході із НС, м; Q - об'ємна витрата води подана ДМ, м³/с; Fвт залежність технологічних втрат води на З3М від напору на виході НC;

Gain 1-Gain 5 - коефіцієнти втрат води, що залежать від довжини ділянок трубопроводів; 2-Кр, 2-1Кр, 2-Кр1, 2-Кр2 - моделі гідравлічних втрат по

довжині трубопроводів; DM-1, DM-2 - моделі ДМ; А, Б, В - точки під'єднання до другої частини моделі

Стабілізацію заданого напору на виході із НС здійснюють застосовуючи ПЧ з ПІ-регулятором. Математичну модель ПІ-регулятора представляють у вигляді паралельно з'єднаних пропорційної та інтегральної ланок з коефіцієнтами передачі $K_{n}$ та $K_{i}$ [8]. Для отримання бажаної якості автоматичного регулювання напору на виході підкачувальної НС, здійснюють оптимізацію параметрів ПІ-регулятора із застосуванням її математичної моделі, наведеної на рис. 7.

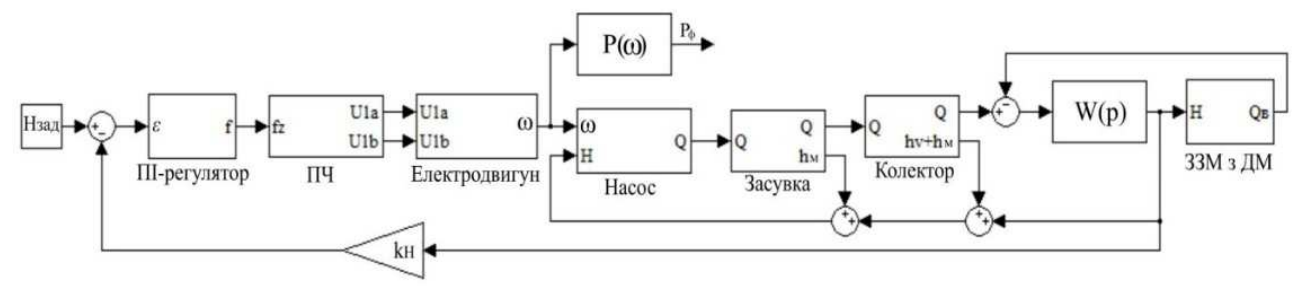

Рис. 7. Математична модель САР напору на виході НС 
Якість автоматичного регулювання напору оцінюють за тривалістю перехідного процесу $\mathrm{T}_{\text {п }}$, а також за величиною середньоквадратичного відхилення від заданого значення впродовж перехідного процесу.

Перехідні процеси регулювання напору води на виході НС, що отримані із застосуванням автоматизованого електропривода НА при нанесенні збурення у вигляді збільшення витрати на $\Delta Q=$ $=0,08 \mathrm{~m}^{3} / \mathrm{c}$, наведені на рис. 8 .
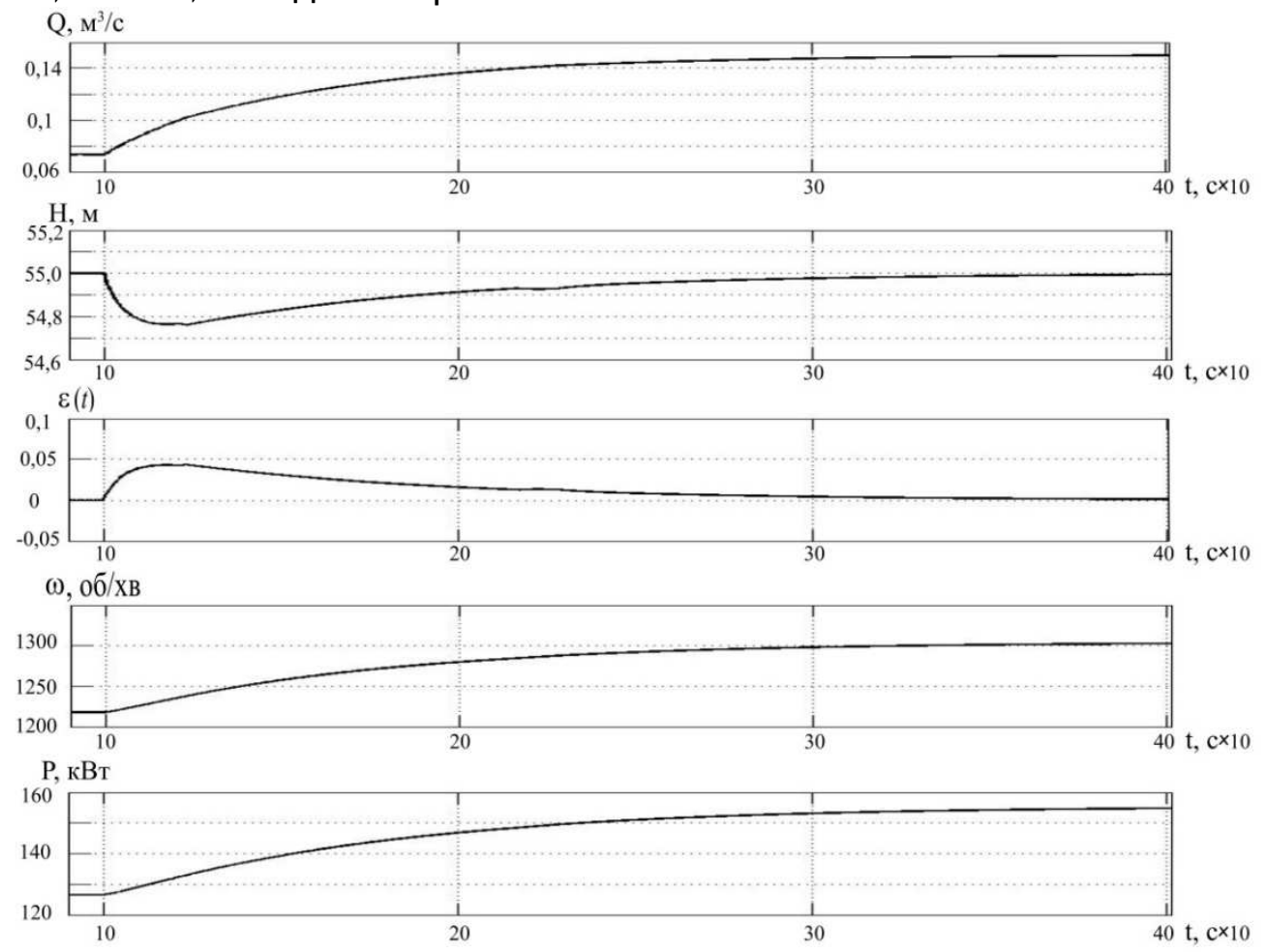

Рис. 8. Оптимізовані перехідні процеси автоматичного регулювання напору води на виході $\mathrm{HC}$ при збільшені витрати води на $\Delta Q=0,08 \mathrm{M}^{3} / \mathrm{c}$

$$
\left(\mathrm{K}_{\mathrm{n}}=0,4, \mathrm{~K}_{\mathrm{i}}=1,23\right) ; \mathrm{T}_{\text {п. }}=300 \mathrm{c} ;|S(\bar{\delta})|=1,2 \%
$$

Висновки. Математична модель системи автоматизованого управління водоподачею, що створена в середовищі MATLAB/Simulink, дозволяє здійснити аналіз та розробити алгоритм автоматизованого управління водоподачею. Доведено, що застосування ПЧ з ПІ-регулятором забезпечує якісне регулювання напору води на виході НС.

1. Трофимов А. И., Егунов Н. Д., Дмитриева А. Н. Методы теории автоматического управления, ориентированы на применение ЭВМ. 
Линейные стационарные и нестационарные модели : учебник для вузов. Москва : Энергоатом издат. 1997. 656 с. 2. Васильев В. В., Симак Л. А., Рыбников А. М. Математическое и компьютерное моделирование процессов и систем в среде MATLAB/Simulink : учебное пособие. Киев : НАН Украины, 2008. 91 с. 3. Попов В. М., Таргоній М. М. Обґрунтування технології автоматизованого управління водоподачею на зрошувальних системах. Меліорація і водне господарство. 2016. Вип. 103. С. 69-73. 4. Попов В. М., Хом'як Б. В. Система для статистичного аналізу процесів водоподачі та електроспоживання на зрошувальних системах із застосуванням ПЕОМ. Меліорація і водне господарство. 2002. Вип. 88. С. 3846. 5. Мошноріз М. Розробка моделі системи керування насосною станцією другого підйому. Наукові праці Вінницького національного технічного університету. 2007. № 1. 6. Лезнов Б. С. Частотно-регулируемый электропривод насосных установок. Москва : Машиностроение, 2013. 176 с. 7. Попов В. М., Таргоній М. М. Моделювання динамічних процесів водоподачі та електроспоживання на зрошувальному технологічному комплексі. Меліорація і водне господарство. 2014. Вип. 101. С. 179-189. 8. Наладка автоматических систем и устройств управления технологическими процесами : справочное пособие / под ред. А. С. Клюева. Москва : Энергия, 1977. 400 с. 9. Методика проведення енергоаудиту на об'єктах водогосподарських систем: НД 33-6.2-01-2006. Київ : Держводгосп України, 2006. 46 с. 10. Справочник по гидравлическим расчетам / под ред. П. Г. Киселева. 5-е. Москва : Энергия, 1974. 312 с. 11. Методологія експериментальних досліджень на закритих зрошувальних системах / Попов В. М. та ін. Вісник НУВГП. Технічні науки. 2016. № 4(76). С. 10-30.

\section{REFERENCES:}

1. Trofimov A. I., Ehunov N. D., Dmitrieva A. N. Metody teorii avtomaticheskoho upravleniia, orientirovany na primenenie EVM. Lineinye statsionarnye i nestatsionarnye modeli : uchebnik dlia vuzov. Moskva : Enerhoatom izdat. 1997. 656 s. 2. Vasilev V. V., Simak L. A., Rybnikov A. M. Matematicheskoe i kompiuternoe modelirovanie protsessov i sistem $v$ srede MATLAB/Simulink: uchebnoe posobie. Kyev : NAN Ukrainy, 2008. 91 s. 3. Popov V. M., Tarhonii M. M. Obgruntuvannia tekhnolohii avtomatyzovanoho upravlinnia vodopodacheiu na zroshuvalnykh systemakh. Melioratsiia $i$ vodne hospodarstvo. 2016. Vyp. 103. S. 69-73. 4. Popov V. M., Khomiak B. V. Systema dlia statystychnoho analizu protsesiv vodopodachi ta elektrospozhyvannia na zroshuvalnykh systemakh iz zastosuvanniam PEOM. Melioratsiia $i$ vodne hospodarstvo. 2002. Vyp. 88. S. 3846. 5. Moshnoriz M. Rozrobka modeli systemy keruvannia nasosnoiu stantsiieiu druhoho pidiomu. Naukovi pratsi Vinnytskoho natsionalnoho tekhnichnoho universytetu. 2007. № 1. 6. Leznov B. S. Chastotno-rehuliruemyi elektroprivod nasosnykh ustanovok. Moskva : Mashynostroenye, 2013. $176 \mathrm{~s}$. 7. Popov V. M., Tarhonii M. M. Modeliuvannia dynamichnykh protsesiv 
vodopodachi ta elektrospozhyvannia na zroshuvalnomu tekhnolohichnomu kompleksi. Melioratsiia i vodne hospodarstvo. 2014. Vyp. 101. S. 179-189. 8. Naladka avtomaticheskikh sistem i ustroistv upravleniia tekhnolohicheskimi protsesami : spravochnoe posobie / pod red. A. S. Kliueva. Moskva : Enerhiia, 1977. 400 s. 9. Metodyka provedennia enerhoaudytu na obiektakh vodohospodarskykh system: ND 33-6.2-01-2006. Kyiv : Derzhvodhosp Ukrainy, 2006. 46 s. 10. Spravochnik po hidravlicheskim raschetam / pod red. P. H. Kiseleva. 5-e. Moskva : Enerhiia, 1974. 312 s. 11. Metodolohiia eksperymentalnykh doslidzhen na zakrytykh zroshuvalnykh systemakh I Popov V. M. ta in. Visnyk NUVHP. Tekhnichni nauky. 2016. № 4(76). S. 10-30.

Popov V. M., Doctor of Engineering, Targonii M. M. (Institute of Water Problems and Land Reclamation, Kyiv)

\section{MATHEMATICAL MODEL OF AUTOMATED WATER SUPPLY CONTROL ON IRRIGATION SYSTEM}

The studies are aimed at creating a mathematical model that is used to substantiate the automated water supply (AWS) algorithms on a closed irrigation system (CIS) when applied to a pump station (PS) with a pump unit (PU) with a frequency converter (FC). The purpose of the research is to reduce the energy consumption of machine water supply at the CIS by effectively applying the FC to the emergency. Main tasks: creation of a model of automated water supply management according to the flow chart of the CIS; identification of parameters of typical model blocks based on the results of experimental studies; quality analysis of the automatic control system (ACS) of the head at the output of the PU. A mathematical model of the CIS was created as an object of dispersed control and automated control of water supply according to its block diagram using MATLAB / Simulink. The dynamic and hydraulic characteristics of the objects were obtained as a result of experimental studies carried out at the CIS using ME. Parameters of typical blocks of mathematical model - asynchronous electric motors, centrifugal pumps, latches and other blocks according to transient characteristics and functional dependences obtained experimentally are identified. The hydraulic characteristics of the closed irrigation network (CIN) were determined using the calculation and experimental method. A mathematical model of the automatic control system (ACS) of the head at the output of the PS has been developed for the analysis of transient processes of automatic regulation of water supply and optimization of the proportional-integral (PI) controller parameters. 
Keywords: mathematical model, automated electric drive, pump unit, water supply control, hydraulic characteristics.

Попов В. Н., д.т.н., Таргоний Н. Н. (Институт водных проблем и мелиорации, г. Киев)

МАТЕМАТИЧЕСКАЯ МОДЕЛЬ АВТОМАТИЗИРОВАННОГО УПРАВЛЕНИЯ ВОДОПОДАЧИ НА ОРОСИТЕЛЬНОЙ СИСТЕМЕ

Исследования направлены на создание математической модели, которая применяется для обоснования алгоритмов автоматизированного управления водоподачи на закрытой оросительной системе (30C) при применении на насосной станции (HC) насосного агрегата (НА) с преобразователем частоты (ПЧ).

Целью исследований является уменьшение энергоемкости машинной водоподачи на 03С путем эффективного применения ПЧ на ЧС. Поставлена задача: создание модели автоматизированного управления водоподачи по блок-схеме 30С; проведение идентификации параметров типовых блоков модели по результатам экспериментальных исследований; анализ качества системы автоматического регулирования (CAP) напора воды на выходе НС.

Создана математическая модель 03С, как объекта рассредоточенного контроля и автоматизированного управления водоподачи, по ее блок-схеме с применением программы MATLAB / Simulink. Получены динамические и гидравлические характеристики объектов по результатам экспериментальных исследований, проведенных на $30 \mathrm{C}$ с применением современных средств измерительной техники. Осуществлена идентификация параметров типовых блоков математической модели - асинхронных электродвигателей, центробежных насосов, задвижек и других блоков по переходным характеристикам и функциональным зависимостям, полученным экспериментально. Определены гидравлические характеристики закрытой оросительной сети с применением расчетноэкспериментального метода. Разработана математическая модель САР напора на выходе НС для анализа переходных процессов автоматического регулирования водоподачи и оптимизации параметров пропорционально-интегрального (ПИ) регулятора.

Ключевые слова: математическая модель, автоматизированный электропривод, насосный агрегат, управление водоподачей, гидравлические характеристики. 